JKKP: Jurnal Kesejahteraan Keluarga dan Pendidikan

http://doi.org/10.21009/JKKP

DOI: doi.org/10.21009/JKKP.031.05

E-ISSN: 2597-4521

\title{
PENGARUH COPING ISTRI TERHADAP KONFLIK PERKAWINAN DI KOTA BOGOR
}

\author{
Rosita ${ }^{1, a)}$, Tarma ${ }^{1, b)}$, Us watun Hasanah ${ }^{1, c)}$ \\ a)rosita.setiawan42@yahoo.com , b)tarmasae@gmail.com, clus nina@yahoo.com \\ 1Program Studi Pendidikan Kesejahteraan Keluarga \\ Fakultas Teknik, Universitas Negeri J akarta \\ J In. Rawamangun Muka, J akarta Timur. 13220
}

\begin{abstract}
Abstrak
Ketika suatu perkawinan sering diwarnai pertengkaran, merasa tidak bahagia, atau masalah lainnya sering kali terpikir untuk segera mengakhiri pernikahan tersebut. Berdasarkan data di Pengadilan Agama Kota Bogor, tahun 2010 jumlah perkara kasus gugat cerai istri sebanyak 708, tahun 2011 perkara kasus gugat cerai istri sebanyak 749 dan tahun 2012-2015 3075 perkara gugat cerai istri. Faktor jenis perkara gugat cerai istri terbanyak setiap tahunnya disebabkan ketidakharmonisan $30 \%$, gangguan pihak ketiga $24 \%$, persoalan ekonomi $20 \%$. Tujuan penelitian ini mengetahui pengaruh coping istri terhadap konflik perkawinan. Penelitian ini dilaksanakan di Kota Bogor. Metode penelitian yang digunakan adalah survei. Penelitian ini menggunakan metode kuantitatif asosiatif. Populasi pada penelitian ini adalah istri yang bekerja di Kota Bogor, jumlah sampel yang digunakan sebanyak 80 orang. Teknik sampling yang digunakan cluster area sampling. Hasil penelitian menunjukkan bahwa terdapat pengaruh yang signifikan antara coping dan konflik perkawinan dengan koefisien korelasi sebesar 0,234 . Hasil uji signifikansi pada koefisiennya sebesar 2,129 dan dapat disimpulkan koefisien korelasi adalah signifikan. Koefisien determinasi yang diperoleh sebesar $6 \%$ menunjukkan variabel konflik perkawinan ditentukan oleh coping. Persamaan regresi yang dihasilkan menunjukkan bahwa setiap peningkatan satu skor coping dapat menyebabkan peningkatan konflik perkawinan istri yang bekerja sebesar 0,18 pada konstanta 24,08 . Hasil uji hipotesis mengatakan terdapat pengaruh yang positif dan siginifikan antara coping dan konflik perkawinan pada istri yang bekerja di Bogor.
\end{abstract}

Kata Kunci: Coping, Konflik Perkawinan, Istri bekerja.

\section{Effect Of Wife Coping Of Marriage Conflict In Bogor}

\begin{abstract}
When a marriage is often quarrel, feel unhappy, or other problems that are often thought to immediately terminate the marriage. Based on data from the R eligious Court of Bogor in 2010, the number of cases of wife divorce as much as 708, in 2011 as much as 749 and in 20122015 as much as 3075. Factors types of wives divorce cases that most occur annually are caused $30 \%$ disharmony, $24 \%$ third party interference, $20 \%$ economic problems. The aims of this study to determine the influence of wife coping on marriage conflict. This research was conducted in Bogor city. The research method used was survey. This study used quantitative methods associative. The population in this study was the wife who works in Bogor city, the number of samples used as many as 80 respondent. The sampling technique used cluster sampling area. The results showed that had a significant difference between coping and marriage conflict with a correlation coefficient of 0.234 . The results of significance test was showed that had a significant correlation with correlation coefficient of 2.129. The coefficient
\end{abstract}


of determination obtained was $6 \%$, showed marriage conflict variable determined by coping. The result of regression equation showed that any increase in the score of coping can lead to increased marriage conflict of working wife by 0.18 at 24.08 constants. Hypothes is test results say there is a positive and significant influence between coping and marital conflict on a wife who works in Bogor.

Keyword: Coping, marital conflict, wife works.

\section{PENDAHULUAN}

Perkawinan merupakan penyatuan dua individu untuk membentuk suatu keluarga. Sebelum masuk pada tahap perkawinan kedua individu harus melalui proses perkenalan antar kedua pihak keluarga, melamar, pertunangan dan kemudian melaksanakan perkawinan. Proses perkenalan yang mendalam antar pasangan dan adanya persetujuan dari keluarga kedua belah pihak akan semakin mengakrabkan kedua keluarga maupun dari calon pasangan tersebut.

Setiap keluarga dibangun dalam suatu ikatan perkawinan yang di sahkan oleh pemerintah dan agama. Pernyataan ini diperkuat dengan UU No.1 Tahun 1974 tentang perkawinan yang tertera pada Pasal 1 Ayat 1 bahwa perkawinan adalah ikatan lahir batin antara seorang pria dan seorang wanita sebagai suami istri dengan tujuan membentuk keluarga atau rumah tangga yang bahagia dan kekal berdasarkan Ketuhanan Yang Maha Esa.

Makna perkawinan adalah ikatan lahir batin antara seorang pria dengan seorang wanita sebagai suami istri dengan tujuan membentuk keluarga yang bahagia. Ikatan batin adalah ikatan yang tidak nampak secara langsung atau ikatan psikologi. Antara suami dan istri harus ada ikatan saling cinta satu dengan yang lain. Ikatan saling cinta ini akan mengikat satu dengan yang lain sehingga akan tercipta hubungan yang harmonis dan saling menjaga satu sama lain. Untuk membentuk keluarga yang bahagia, suami istri harus memahami fungsi keluarga dan peran masingmasing.

Berdasarkan data di Pengadilan Agama Kota Bogor, tahun 2010 jumlah perkara kasus gugat cerai istri sebanyak 708, tahun 2011 perkara kasus gugat cerai istri sebanyak 749 dan tahun 201220153075 perkara gugat cerai istri (Badan Peradilan Agama, 2014). Faktor jenis perkara gugat cerai istri terbanyak setiap tahunnya disebabkan ketidakharmonisan $30 \%$, gangguan pihak ketiga $24 \%$, persoalan ekonomi $20 \%$. Konflik dalam perkawinan bergantung pada kebahagiaan salah satu pasangan dengan hubungan mereka, sensitivitas mereka satu sama lain, validasi mereka terhadap perasaan satu sama lain, serta keterampilan komunikasi dan manajemen konflik mereka. Tujuan penelitian ini untuk mengetahui pengaruh coping istri terhadap konflik perkawinan.

\section{METODOLOGI}

Penelitian ini dilaksanakan di RW 08 Kelurahan Pasir Kuda Kecamatan Bogor Barat Kota Bogor. Tempat ini dipilih karena peneliti menemukan kasus gugat cerai istri yang tinggi. Di tahun terakhir dapat dilihat berdasarkan data Badilag Kota Bogor dalam angka tahun 2014 sebesar 1000 kasus, telah terjadi peningkatan sebanyak 78 kasus menjadi 1078 kasus. Adapun penelitian dilaksanakan mulai dari Maret hingga Mei 2016.

Metode penelitian yang digunakan adalah survei. Penelitian ini menggunakan metode kuantitatif asosiatif. Populasi pada penelitian ini adalah istri yang bekerja dan memiliki suami dan anak. Jumlah sampel yang digunakan sebanyak 80 orang Sampel adalah bagian dari jumlah dan karakteristik yang dimiliki oleh populasi tersebut (Sugiyono, 2014). Jumlah populasi yang besar dan peneliti tidak mungkin mempelajari semua yang ada pada populasi. Sampel ini adalah istri dengan karakteristik sebagai berikut: 
1. Sudah menikah

2. Bekerja

3. Usia 18-40

4. Masih memiliki suami

Sugiyono (2010) menyatakan bahwa ukuran sampel yang layak dalam penelitian adalah antara 30-500 dan apabila dalam penelitian akan dilakukan analisis multivariate (misalnya, korelasi atau regresi ganda), maka jumlah sampel minimal 10 kali jumlah variabel. Oleh karena itu, dalam penelitian ini peneliti mengambil data dengan sampel lebih dari 30 orang untuk memenuhi syarat tersebut.

Dalam penelitian ini, untuk dapat meneliti pengaruh coping istri terhadap konflik perkawinan di Kota Bogor menggunakan metode kuantitatif dengan jenis metode survei korelasional. Teknik yang digunakan dalam menentukan sampel yaitu dengan menggunakan teknik cluster area sampling. Menurut Margono (2004: 127), teknik ini digunakan untuk populasi yang tidak terdiri dari individu-individu tapi terdiri dari kelompok-kelompok individu atau cluster.

\section{HASIL DAN PEMBAHASAN}

Berdasarkan penelitian yang telah dilakukan, diketahui nilai koefisien korelasi rxy sebesar 0,234 dan thitung sebesar 2,129 > ttabel sebesar 1,99 sehingga dapat disimpulkan bahwa terdapat hubungan positif antara Coping dengan Konflik Perkawinan pada Istri yang bekerja maupun tidak bekerja di Kota Bogor. Nilai ini menunjukkan bahwa semakin tinggi Coping maka semakin tinggi Konflik Perkawinan pada Istri yang bekerja maupun tidak bekerja di Kota Bogor.

Variabel Coping yang diukur dari dimensi Emotion Focused Coping dan Problem Focused Coping. Berdasarkan hasil perhitungan interpretasi data variabel coping dimensi Emotion Focused Coping lebih sering digunakan oleh istri bekerja maupun tidak bekerja di Kota Bogor sebanyak $68 \%$ dibanding Problem Focused Coping yang hanya sebanyak $61 \%$. Hal ini sejalan dengan penelitian yang dilakukan Billings \& Moos (dalam Pramadi \& Lasmono, 2003), dalam menghadapi suatu masalah yang dapat menimbulkan stress wanita memiliki kecenderungan menggunakan Emotion Focused Coping.

Jika dilihat dari perhitungan variabel coping dimensi Emotion Focused Coping, dengan indikator tertinggi indikator memikirkan hal positif. Hal ini berarti istri yang bekerja maupun tidak bekerja di Kota Bogor ketika dihadapi dengan suatu masalah mencoba untuk memikirkan hal positif. Mayoritas responden istri yang bekerja maupun tidak bekerja di Kota Bogor menjawab sangat kuat, menandakan responden berpikir bahwa setiap masalah pasti ada jalan keluar. Memikirkan hal positif merupakan sumber kekuatan karena membantu untuk memikirkan sampai mendapatkan solusinya (Elfiky, 2009).

Indikator terendah mencari akar masalah, menandakan bahwa istri yang bekerja maupun tidak bekerja di Kota Bogor kurang mampu mencari akar masalah yang di hadapi, hal tersebut dikarenakan berbagai kurangnya pengetahuan responden mengenai langkah awal yang harus diambil dalam mencari akar masalah. Sebab masalah-masalah yang harus dihadapi orang dewasa itu rumit dan memerlukan waktu dan energi untuk di atasi, maka berbagai penyesuaian diri terhadap masalah yang dihadapi (Hurlock,1980).

Jika dilihat dari perhitungan variabel coping pada dimensi Problem Focused Coping, indikator dengan persentase tertinggi yaitu melakukan pendekatan kepada Tuhan Yang Maha Esa. Hal ini mengartikan istri yang bekerja maupun tidak bekerja di Kota Bogor memiliki spritualitas yang baik kepada Tuhan. Mayoritas respoden menjawab sangat kuat dalam hal tersebut. Spritualitas dan keimanan merupakan dimensi yang paling kuat bagi pengalaman manusia. Spritualitas merujuk pada kualitas batin yang dirasakan individu dalam hubungannya dengan Tuhan, makhluk lain dan nurani (Sri Lestari, 2012). 
Indikator terendah dari dimensi Problem Focused Coping yaitu melakukan kegiatan fisik meliputi berbagai aktifitas pengalihan dari masalah yang dihadapi. Istri yang bekerja maupun tidak bekerja merasa tidak kuat untuk melakukan kegiatan aktifitas rumah tangga seperti menyapu dan mengepel. Fase keletihan menghadapi masalah ini menyebabkan individu tidak mampu melakukan kegiatan fisik (Sarafino, 2006).

Indikator mengendalikan emosi, indikator ini lebih kepada pengontrolan emosi ketika menghadapi masalah. Emosi cenderung terkait stres, individu sering menggunakan keadaan emosionalnya untuk mengevaluasi stres dan pengalaman emosional (Sarafino, 2006). Indikator meminta pendapat lingkungan, lingkungan sosial dapat menjadi alternatif bagi individu untuk meminta pendapat atas masalah yang dihadapinya Meminta pendapat lingkungan sosial bisa menjadi dukungan sosial yang diberikan oleh lingkungan masyarakat, orang tua, anggota keluarga lain, saudara dan teman. Dukungan ini meliputi dukungan pemenuhan kebutuhan informasi dan emosional (Mutadin, 2002).

Selain itu, istri yang bekerja maupun tidak bekerja tersebut dapat mempertahankan situasisituasi yang mendukung mereka dalam melakukan coping. Salah satu yang dapat digunakan memunculkan perilaku memelihara atau menjaga hubungan dan menunjukkan pada pasangan usaha terbaiknya (Reis \& Sprecher, 2009).

\section{KESIMPULAN}

Hasil uji signifikansi pada koefisiennya sebesar 2,129 dan dapat disimpulkan koefisien korelasi adalah signifikan. Koefisien determinasi yang diperoleh sebesar $61 \%$ menunjukkan variabel konflik perkawinan ditentukan oleh coping. Persamaan regresi yang dihasilkan menunjukkan bahwa setiap peningkatan satu skor coping dapat menyebabkan peningkatan konflik perkawinan istri yang bekerja sebesar 0,18 pada konstanta 24,08 . Hasil uji hipotesis mengatakan terdapat pengaruh yang positif dan siginifikan antara coping dan konflik perkawinan pada istri yang bekerja di Bogor, dimana semakin tinggi Coping maka semakin tinggi konflik perkawinan pada Istri yang bekerja maupun tidak bekerja di Kota Bogor.

\section{DAFTAR PUSTAKA}

Badan Peradilan Agama. 2014. Grafik penyebab gugat cerai istri di Peradilan Agama Tahun 2010-2015. Infoerkara.nadilag.net. T anggal akses 2 Maret 2016.

Elfiky, I. 2009. Terapi Berfikir Positif. Zaman, Jakarta

Hurlock, E.B. 1980. Psikologi Perkembangan Suatu Pendekatan Sepanjang Rentang Kehidupan Edisi 5. Erlangga. Jakarta.

Lestari, S. 2012. Psikologi Keluarga Penanaman Nilai dan Penanganan Konflik dalam Keluarga. Kencana Prenada Media Group. Jakarta

Sarafino, E.P. 2006. Health Psychology : Biopsychosocial Interactions. Fifth E dition. John Wiley \& Sons. USA.

Sugiyono. 2014. Metode Penelitian Pendidikan Pendekatan Kuantitatif, Kualitatif, dan R\&D. Alfabeta. Bandung

Margono. 2004. Metodologi Penelitian Pendidikan. Rineka Cipta. Jakarta 